Szegedi Tudományegyetem, Gyógyszerésztudományi Kar, Gyógyszertechnológiai és Gyógyszerfelügyeleti Intézet*

Szegedi Tudományegyetem, Általános Orvostudományi Kar, Klinikai Mikrobiológiai Diagnosztikai Intézet**

Szegedi Tudományegyetem, Fogorvostudományi Kar, Parodontológiai Tanszék ${ }^{\star \star *}$

\title{
Klórhexidint tartalmazó, kontrollált hatóanyag-leadást biztosító, szubgingiválisan alkalmazható készítmény keménységének és hatóanyag-leadásának vizsgálata
}

\author{
DR. BUDAI-SZÜCS MÁRIA*, DR. LÉBER ATTILA*, DR. BURIÁN KATALIN*, DR. KOVÁCS ANITA*,
} DR. BERKÓ SZILVIA*, DR. GÁCSI ATTILA*, DR. CSÁNYI ERZSÉBET*, DR. VÁLYI PÉTER ${ }^{* *}$

\begin{abstract}
A destruktív fogágybetegség kezelése során a mechanikai plakkeltávolításon kívül az antiszeptikumoknak is fontos szerepe van. A szubgingiválisan alkalmazható, klórhexidin-diglükonátot (CHX) tartalmazó hatóanyag-hordozó rendszerek fokozhatják a nem sebészi terápia hatását vagy bizonyos esetekben ki is válthatják azt. Jelen közleményben egy saját fejlesztésű, CHX-t tartalmazó, szilárd, de testhőmérsékleten meglágyuló rendszer keménységét, hatóanyag-leadását és antimikrobiális hatékonyságát vizsgáltuk. A keménységet textúraanalizáló készülék segítségével 25 és $37^{\circ} \mathrm{C}$-on, a hatóanyag-diffúziót PBS-oldatban egy héten keresztül, a mikrobiológiai hatékonyságot pedig 6 anaerob baktériumtörzsön vizsgáltuk. Az eredmények alapján a hordozórendszerek szobahőmérsékleten jól kezelhetők, $37^{\circ} \mathrm{C}$-on kellő mértékben lágyulnak és így képesek felvenni a tasak alakját. A rendszerek nyújtott hatóanyag-diffúziót képesek biztosítani, 1 hét alatt a hatóanyag kb. 50\%-a diffundált ki, megfelelő $8 \mu \mathrm{g} / \mathrm{ml}$-es koncentrációt tartva. A készítmény legalább egy héten keresztül képes gátolni a vizsgált anaerob baktériumok szaporodását. Eredményeink szerint a vizsgált rendszer önállóan vagy a mechanikai terápia kiegészítőjeként hatékony lehet a fogágybetegség kezelése során.
\end{abstract}

Kulcsszavak: fogágybetegség, klórhexidin-diglükonát, hatóanyag-diffúzió, antibakteriális hatékonyság

\section{Bevezetés}

A destruktív fogágybetegség egy komplex megbetegedés, számos etiológiai és rizikótényezőnek köszönhető, alapvetően infekciós eredetú kórkép, amelynek megelőzése és terápiája a mikroorganizmusok szupraés szubgingivális kolonizációjának és szaporodásának megakadályozásán alapszik. Az elsősorban baktériumok - de fontos szereplők a herpeszvírusok is - által kialakított ökológiai egységek, a természetes és mesterséges kemény felszíneken kialakuló biofilmek nagy részének eliminálását a mechanikai plakkeltávolítás módszerei segítségével végezzük, de az antibiotikumoknak és antiszeptikumoknak is fontos szerepe van abban, hogy a fertőző ágensek mennyisége a betegséget kiváltó és fenntartó szint alatt maradjon [20].

Az antiszeptikumok között ma is "gold standardként" számontartott klórhexidint [10] széleskörǔen alkalmazzuk a nem sebészi terápia részeként, köszönhetően annak, hogy plakk-gátló hatással rendelkezik. Leggyakrabban szájöblítőként használjuk, amelynek során nemcsak a szupragingivális biofilm mikroorganizmusainak számát redukálja, de a szubgingivális tér rekolonizációját is képes késleltetni, valamint más - mechanikai terápiával nem elérhető - reinfekciót okozó intraorális rezervoár (nyelvhát és más szájnyálkahártya területek) csíraszámának csökkentésében is lényeges szerepe van [7]. Lokális szubgingivális alkalmazásának többféle célja van: a mechanikai terápia hatásának fokozására, a szubgingivális terület ökológiai réseiben megbújó baktériumok elpusztítására irrigálószerként; egy-egy aktív vagy a mechanikai terápiára nem reagáló, esetleg rekurráló lézió anti-infektív terápiájában kontrolláltan felszívódó, több napig egyenletes hatóanyagleadást biztosító készítményben használhatjuk [7]. Kiegészítő hatása fontos lehet akkor, ha a páciens egyéb rizikótényezővel is bír, így például dohányzó és/vagy diabetes mellitusban is szenved [7].

A lokális antimikrobiális készítmények fokozzák a mechanikai nem sebészi terápia hatását, elsősorban a közepesen mély tasakok esetében kiválthatják vagy késleltethetik a sebészi terápiát [7]. A szisztémásan adott készítményekhez képest a lokális terápia előnyösebb az antibiotikum-rezisztencia kialakulása szempontjából, de használati értékük megítélése kérdéses [15], ami nem az alkalmazott antibiotikumok, antiszeptikumok hatásfokával, hanem számos, a klinikai gyakorlatban előforduló problémával magyarázható. Elsősorban a költséghatékonyság miatt több készítményt már kivontak a piacról, néhány alkalmazása nehézkes, időigényes, illet- 
ve van olyan készítmény, amely idő előtt felszívódik vagy nem biztosít egyenletes hatóanyag-leadást $[7,15]$. A fentiek alapján, a lokális antimikrobiális készítményeknek helyük van a parodontitis, illetve a peri-implantitis terápiájában. A költséghatékonyságot és a készítmények elvárt tulajdonságait figyelembe véve, az ideális vivőrendszerek fejlesztésére nagy igény van, hiszen azok az ismert hatóanyagok eddigieknél szélesebb körü, biztosabb és jobb eredményekkel kecsegtető alkalmazását tennék lehetővé.

Célunk egy olyan biodegradábilis és biokompatibilis, klórhexidint tartalmazó, lipid alapú hatóanyag-hordozó létrehozása, amely a parodontális tasakba helyezve, hosszan tartó (legalább 7 napos) hatóanyag-diffúziót képes biztosítani, testhőmérsékleten meglágyul, így igazodik a parodontális tasak alakjához, és gátolni tudja a betegség kialakulásában résztvevő anaerob baktériumok szaporodását. Jelen közleményünkben a készítmény keménységének és a hatóanyag-leadás dinamikájának a vizsgálatáról számolunk be. A klórhexidin felszabadulását a fogágy destrukcióját okozó baktériumokra kifejtett gátló hatás révén is mértük.

\section{Anyagok és módszerek}

A készítmények előállításához az alábbi anyagokat használtuk fel: alapként Suppocire BP-t (SBP) (Gattefossé, Sain-Priest, Franciaország), vázképző komponensként cetil-sztearil-alkoholt (CA) (Ph. Eur. 8., Hungaropharma ZRT., Budapest, Magyarország), emulgensként Kolli phor RH40-et (KP) (BASF Chemtrade GmbH, Ludwigshafen, Németország), duzzadást és mukoadhéziót segítő komponensként Methocel E4M-et (HPMC) (Colorcon Ltd., Colorcon Ltd., Dartford, Egyesült Királyság), valamint hatóanyagként $20 \%$-os klórhexidin-diglükonát (CHX) oldatot (Ph. Eur. 8., Hungaropharma ZRT., Budapest, Magyarország). Minden hatóanyag-hordozó az alábbi anyagokat tartalmazza: 43,0\% SBP, 40\% CA; $10 \% \mathrm{KP} ; 2 \% \mathrm{HPMC} ; 5 \% \mathrm{CHX}$. Ezen összetétel a hatóanyag mennyiségéből eredő hordozókorrekcióval megfelel a korábbi publikációnkban ismertetett, legjobbnak ítélt összetételnek [13].

Az előállítást olvasztásos módszerrel végeztük. A SBP-t, $\mathrm{KP}$-t és CA-t $70^{\circ} \mathrm{C}$-on, folyamatos keverés mellett öszszeolvasztottuk, majd a homogén és még folyékony keverékhez $50{ }^{\circ} \mathrm{C}$-on adtuk hozzá a HPMC-t és a $20 \%$-os $\mathrm{CHX}$-oldatot. A keveréket $1 \mathrm{~mm}$ magasságú és $9 \mathrm{~mm}$ átmérőjű henger formába öntöttük. A mintákat a vizsgálatokat megelőző 24 órában $25^{\circ} \mathrm{C}$-on tároltuk.

A rendszerek keménységét egy 5 kg-os mérőcellával felszerelt TA.XTPlusC (Godalming, Surrey, Egyesült Királyság) készülékkel vizsgáltuk 25 és $37^{\circ} \mathrm{C}$-on, az utóbbi esetben vizes közegben a behelyezést követő 10. percet imitálva. A vizsgálat során egy $5 \mathrm{~mm}$ átmérőjú gömb alakú szonda hatolt be a minta $50 \%$-os mélységéig $(0,5 \mathrm{~mm})$.

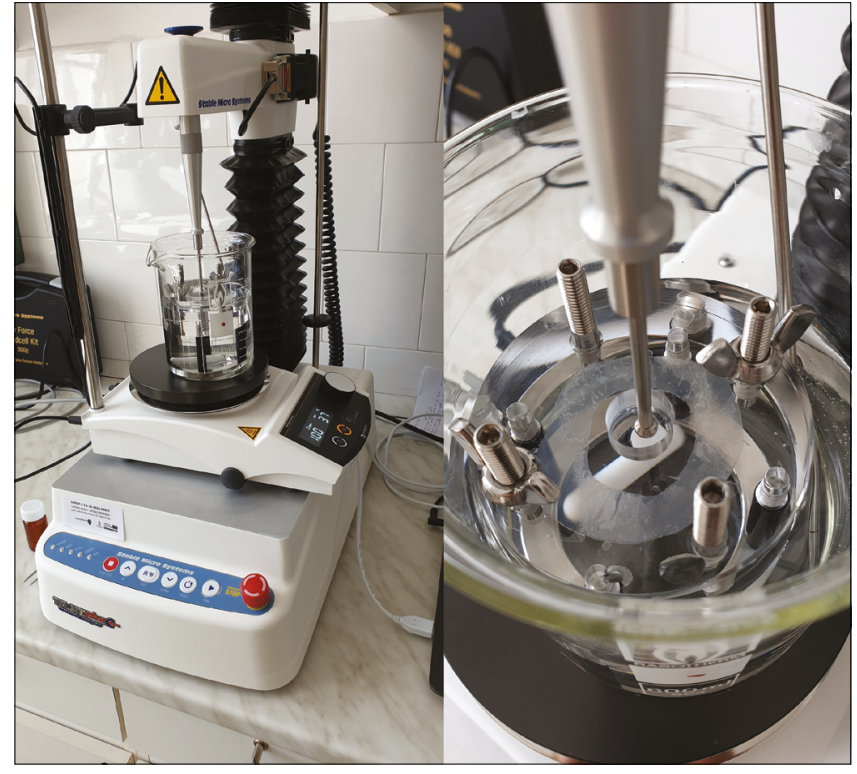

1. kép: A rendszerek keménységének vizsgálatára használt berendezés

A rendszerekből diffundálódó hatóanyag mennyiségének in vitro meghatározása során, a hatóanyag-hordozókat dializáló csövekbe (Spectra/Por ${ }^{\circledR}$ Standard RC tubing, MWCO: 12-14 kD) tettük, amelyeknek két végét lezártuk. A dializáló cső 12000 D alatti molekulákat átenged, így a $\mathrm{CHX}$ diffúzóját nem gátolja. A rendszereket tartalmazó dializáló csöveket $7,5 \mathrm{ml} 37^{\circ} \mathrm{C}$-ra termosztált PBS-oldatba helyeztük, majd 0,$5 ; 1 ; 2 ; 4$; $6 ; 8 ; 24 ; 36 ; 48 ; 56 ; 72 ; 80 ; 96$ és 170,5 órát követően $2,5 \mathrm{ml}$ mintát vettünk, amelyet minden mintavételi alkalommal $37^{\circ} \mathrm{C}$-os tiszta PBS-oldattal pótoltunk. A minták CHX-tartalmát UV-Vis spektroszkópiával határoztuk meg 250 nm-en, előzetesen felvett kalibrációs görbe segítségével (R2 = 0,9971). A készítményből felszabadult hatóanyag kvantitatív mérését megelőzte a hatóanyagmentes hordozó vizsgálata, amely az UV-Vis technika szelektivitását igazolta $\mathrm{CHX}$-re.

A rendszerek mikrobiológiai hatékonyságát az alábbi 6 db anaerob patogén baktériumon vizsgáltuk: Fusobacterium nucleatum, Porphyromonas gingivalis, Eikenella corrodens, Prevotella intermedia, Parvimonas micra és Aggregatibacter actinomycetemcomitans. A vizsgálat során az egyes baktériumokból külön-külön 1 McFarland-sztenderdnek megfelelő baktériumszuszpenziókat készítettünk. Ezt követően a szuszpenziókat 5\% juhvért tartalmazó Schaedler-agarra oltottuk, majd a beoltott táptalajra helyeztük a készítményt. A táptalajokat 24 órán keresztül anaerob körülmények között inkubáltuk. 24 óra múlva a hatóanyag-hordozó körül kialakuló gátlási zóna átmérőjét megmértük. Ezt követően friss baktériumszuszpenziókat készítettünk, majd újabb táptalajokat oltottunk be, amelyekre áthelyeztük a készítményeket, majd a táptalajokat azonos körülmények között 24 órán keresztül inkubáltuk. 24 órát követően újra leol- 
vastuk a rendszerek körül kialakult gátlási zóna átmérőjét. A rendszerek friss táptalajra történő áthelyezését és inkubálását addig folytattuk, amíg a hordozórendszer körül már hiányzott a gátlási zóna.

\section{Eredmények}

A rendszerek keménységének meghatározását szobahőmérsékleten és $37^{\circ} \mathrm{C}$-on, a szájban lévő nedves körülményeket imitálva pufferoldatban végeztük el. A vizsgálat során olyan beálítást alkalmaztunk, amely a hatóanyag-hordozókat 50\%-ban deformálja, azaz az 1,00 mm vastag rendszerekbe a szonda $0,50 \mathrm{~mm}$ mélyen hatolt be.

A vizsgálat eredményei alapján (2. kép) megállapítható, hogy míg $25^{\circ} \mathrm{C}$-on a száraz rendszerek deformációjához $2074 \pm 48 \mathrm{mN}$ erő szükséges, addig $37^{\circ} \mathrm{C}$-on nedves körülmények között ez az érték kevesebb mint felére, azaz $810 \pm 116$ mN-ra csökken.

A hatóanyag-diffúzió vizsgálata során a formulációkat dializáló csőbe helyeztük. A dializáló cső falán keresztül a hatóanyag és a kioldóközeg szabadon képes diffundálni. A vizsgálat során ez egyfajta szűrőként viselkedik, amely a spektrofotometriás mérést zavaró, oldódó komponenseket nem engedi a kioldó közegbe jutni. A dializáló cső jelenléte a vizsgálat szempontjából lényeges komponens ( $\mathrm{a} \mathrm{CHX}$ ) diffúzióját nem gátolja.

A hatóanyagdiffúziós vizsgálat eredményei alapján (3. kép) megállapítható, hogy 170,5 óra alatt az inkorporált hatóanyag közel 50\%-a diffundált a rendszerekből, ami átlagosan kb. 225 g hatóanyagnak felel meg.

Átlagosan a hatóanyag kb. 19\%-a (83 $\mu \mathrm{g})$ szabadult fel 24 órát követően a rendszerekből, míg 48 óra után ez az érték kicsivel több mint 23\% (128 $\mu \mathrm{g})$. A diffúziós görbén 170,5 óra elteltével sem jelentkezik platófázis, azaz a diffúzió ezt követően folytatódik.

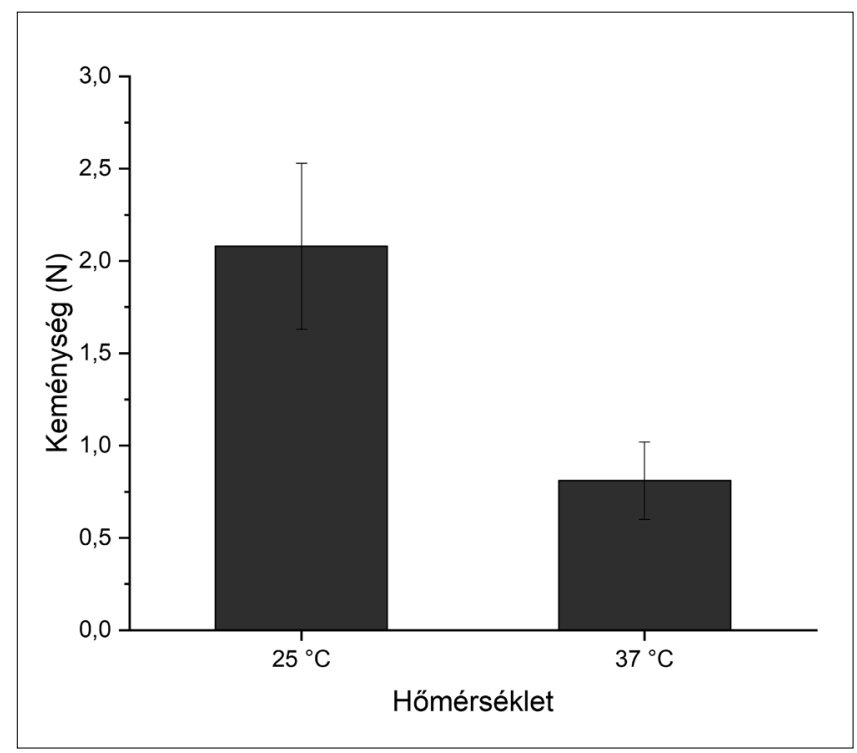

2. kép: A rendszerek keménysége $25^{\circ} \mathrm{C}$-on száraz és $37^{\circ} \mathrm{C}$-on nedves körülmények között
A rendszerek mikrobiológiai hatékonyságának vizsgálatát $6 \mathrm{db}$ anaerob, a betegség kialakulásában résztvevő patogén baktériumtörzsön végeztük el agardiffúziós módszerrel. A vizsgálat során a rendszer körül megjelenő gátlási zónák átmérőjét (Táblázat), valamint a hatóanyag-hordozók által kifejtett gátló hatás hosszát (4. kép) is vizsgáltuk. A vizsgálat során, ha egyáltalán nem volt észlelhető baktérium a táptalajon, a gátlási zóna méretét - a táptalaj átmérőjének megfelelően - 90 mm-nek vettük.

Az eredmények alapján elmondható, hogy a $\mathrm{CHX}$ minden vizsgált baktériumtörzzsel szemben hatékony. A $P$. intermedia és $P$. gingivalis esetében a gátlás hoszszabb időn keresztül is teljes volt, tehát a táptalajon nem volt megfigyelhető baktériumtelep, azonban a gátlási zónák mérete a 90,0 mm-es gátlási zónákat követő napokban 20,0 $\mathrm{mm}$ alá esett.

Az E. corrodens esetében is megfigyelhető egy egynapos teljes gátlás, melyet nagymértékű átmérőcsökkenés követ. Az eredmények között megfigyelhető a gátlási zónák időnkénti növekedése is.

A legkisebb kezdeti gátlási zónák (18,7 mm) az A. actinomycetemcomitans esetében figyelhetők meg, ami kis mértékben tovább csökken az újabb áthelyezéseket követően.

A $P$. micra és az $F$. nucleatum növekedése közepes mértékben gátolt: a zónák mérete $\mathrm{kb}$. 35-40 mm. $E$ két baktériumtörzs esetében is megfigyelhető a kísérlet előrehaladása során a gátlási zónák átmérőjének növekedése (az $F$. nucleatumnál 21,0 mm-ről 43,3 mm-re, A $P$. micránál 16,3 mm-ről 18,7 mm-re és 11,3 mm-ről 12,0 mm-re).

A baktériumok szaporodásának gátlásáról elmondható, hogy a rendszerek legalább 10 napon keresztül hatékonynak bizonyultak. A rendszerek az $A$. actinomycetemcomitans szaporodását voltak képesek gátolni a legrövidebb ideig: 10 napig; az $F$. nucleatum és a $P$. micra esetében pedig a leghosszabb ideig: 15 napig. A felszabaduló $\mathrm{CHX}$ a $P$. gingivalis szaporodását 13 napig, az $E$. corrodensét 11 napig, míg a $P$. intermediáét 12 napig gátolta.

\section{Megbeszélés}

A destruktív fogágygyulladás terápiájában alkalmazott mechanikai plakkeltávolítás szignifikáns javulást eredményez mind a klinikai, mind a mikrobiológiai paraméterekben, de nem alkalmas az összes parodontopatogén mikroorganizmus eliminálására, azok a szubgingivális és intraorális ökológiai résekben túlélhetik a kezelést és reinfekciót okozhatnak [8, 19]. A mechanikai terápia hatékonyságának javítására már régóta alkalmazzuk korlátozott indikációban a szubgingivális térbe helyezhető, kontrollált hatóanyag-leadást biztosító rendszereket [4]. Ezeknek a készítményeknek többféle követelménynek kell megfelelniük. A tasakba helyezve mind a kemény-, mind a lágyszövetek teljes felszínét el kell érniük, kellő 
Táblázat

A kísérletben alkalmazott baktériumtörzsekre vonatkozó gátlási zónák átmérője (mm-ben) a megadott napon

\begin{tabular}{|c|c|c|c|c|c|c|c|c|c|c|c|c|c|c|c|c|}
\hline \multirow{3}{*}{ Baktériumtörzs } & \multicolumn{16}{|c|}{ Idő (nap) } \\
\hline & 1 & 2 & 3 & 4 & 5 & 6 & 7 & 8 & 9 & 10 & 11 & 12 & 13 & 14 & 15 & 16 \\
\hline & \multicolumn{16}{|c|}{ A gátlási zóna átmérője $(\mathrm{mm})$ és az átmérők szórása } \\
\hline A. actinomycetemcomitans & $\begin{array}{c}18,7 \\
\pm \\
0,6\end{array}$ & $\begin{array}{c}15,7 \\
\pm \\
2,9\end{array}$ & $\begin{array}{c}14,7 \\
\pm \\
1,2\end{array}$ & \begin{tabular}{|c|}
13,3 \\
\pm \\
1,2
\end{tabular} & $\begin{array}{c}13,7 \\
\pm \\
2,9\end{array}$ & - & - & $\begin{array}{c}8,0 \\
\pm \\
6,9\end{array}$ & \begin{tabular}{c|}
8,0 \\
\pm \\
6,9
\end{tabular} & $\begin{array}{c}7,3 \\
\pm \\
6,4\end{array}$ & $\begin{array}{c}0,0 \\
\pm \\
0,0\end{array}$ & - & - & - & - & - \\
\hline P. micra & $\begin{array}{c}34,3 \\
\pm \\
7,5\end{array}$ & $\begin{array}{c}15,7 \\
\pm \\
2,1 \\
\end{array}$ & $\begin{array}{c}16,3 \\
\pm \\
1,5\end{array}$ & \begin{tabular}{|c|}
16,3 \\
\pm \\
1,5 \\
\end{tabular} & - & - & $\begin{array}{c}18,7 \\
\pm \\
3,1\end{array}$ & $\begin{array}{c}16,0 \\
\pm \\
2,0\end{array}$ & $\begin{array}{c}14,3 \\
\pm \\
1,5 \\
\end{array}$ & $\begin{array}{c}13,3 \\
\pm \\
2,3 \\
\end{array}$ & $\begin{array}{c}11,3 \\
\pm \\
1,2\end{array}$ & - & - & $\begin{array}{c}12,0 \\
\pm \\
1,0\end{array}$ & $\begin{array}{c}10,7 \\
\pm \\
0,6\end{array}$ & $\begin{array}{c}0,0 \\
\pm \\
0,0\end{array}$ \\
\hline P. intermedia & $\begin{array}{c}90,0 \\
\pm \\
0,0\end{array}$ & $\begin{array}{c}90,0 \\
\pm \\
0,0\end{array}$ & $\begin{array}{c}90,0 \\
\pm \\
0,0\end{array}$ & \begin{tabular}{|c|}
90,0 \\
\pm \\
0,0
\end{tabular} & $\begin{array}{c}90,0 \\
\pm \\
0,0\end{array}$ & - & - & $\begin{array}{c}90,0 \\
\pm \\
0,0\end{array}$ & $\begin{array}{c}90,0 \\
\pm \\
0,0\end{array}$ & $\begin{array}{c}90,0 \\
\pm \\
0,0\end{array}$ & $\begin{array}{c}15,7 \\
\pm \\
0,6\end{array}$ & $\begin{array}{c}13,3 \\
\pm \\
2,3\end{array}$ & $\begin{array}{c}0,0 \\
\pm \\
0,0\end{array}$ & - & - & - \\
\hline E. corrodens & $\begin{array}{c}90,0 \\
\pm \\
0,0\end{array}$ & $\begin{array}{c}24,0 \\
\pm \\
8,7\end{array}$ & $\begin{array}{c}27,3 \\
\pm \\
3,1\end{array}$ & \begin{tabular}{|c|}
30,0 \\
\pm \\
5,3 \\
\end{tabular} & - & - & $\begin{array}{c}15,3 \\
\pm \\
1,5\end{array}$ & - & $\begin{array}{c}16,0 \\
\pm \\
1,7\end{array}$ & $\begin{array}{c}12,7 \\
\pm \\
0,6\end{array}$ & $\begin{array}{c}11,3 \\
\pm \\
1,2\end{array}$ & $\begin{array}{c}0,0 \\
\pm \\
0,0\end{array}$ & - & - & - & - \\
\hline P. gingivalis & $\begin{array}{c}90,0 \\
\pm \\
0,0\end{array}$ & $\begin{array}{c}90,0 \\
\pm \\
0,0\end{array}$ & $\begin{array}{c}90,0 \\
\pm \\
0,0\end{array}$ & \begin{tabular}{|c|}
90,0 \\
\pm \\
0,0
\end{tabular} & $\begin{array}{c}20,0 \\
\pm \\
1,7\end{array}$ & - & - & $\begin{array}{c}17,7 \\
\pm \\
1,2\end{array}$ & $\begin{array}{c}15,3 \\
\pm \\
0,6\end{array}$ & $\begin{array}{c}14,7 \\
\pm \\
1,2\end{array}$ & $\begin{array}{c}14,7 \\
\pm \\
1,2\end{array}$ & $\begin{array}{c}13,0 \\
\pm \\
1,7\end{array}$ & $\begin{array}{c}0,0 \\
\pm \\
0,0\end{array}$ & - & - & - \\
\hline F. nucleatum & $\begin{array}{c}40,7 \\
\pm \\
2,3\end{array}$ & $\begin{array}{c}35,0 \\
\pm \\
3,0\end{array}$ & $\begin{array}{c}32,0 \\
\pm \\
4,0\end{array}$ & \begin{tabular}{|c|}
21,0 \\
\pm \\
1,0
\end{tabular} & - & - & $\begin{array}{c}43,3 \\
\pm \\
3,1\end{array}$ & $\begin{array}{c}37,3 \\
\pm \\
3,1\end{array}$ & $\begin{array}{c}30,0 \\
\pm \\
2,0\end{array}$ & \begin{tabular}{c|}
15,3 \\
\pm \\
2,9
\end{tabular} & $\begin{array}{c}17,3 \\
\pm \\
3,1\end{array}$ & - & - & $\begin{array}{c}14,0 \\
\pm \\
2,6\end{array}$ & \begin{tabular}{c|}
10,7 \\
\pm \\
0,6
\end{tabular} & $\begin{array}{c}0,0 \\
\pm \\
0,0\end{array}$ \\
\hline
\end{tabular}

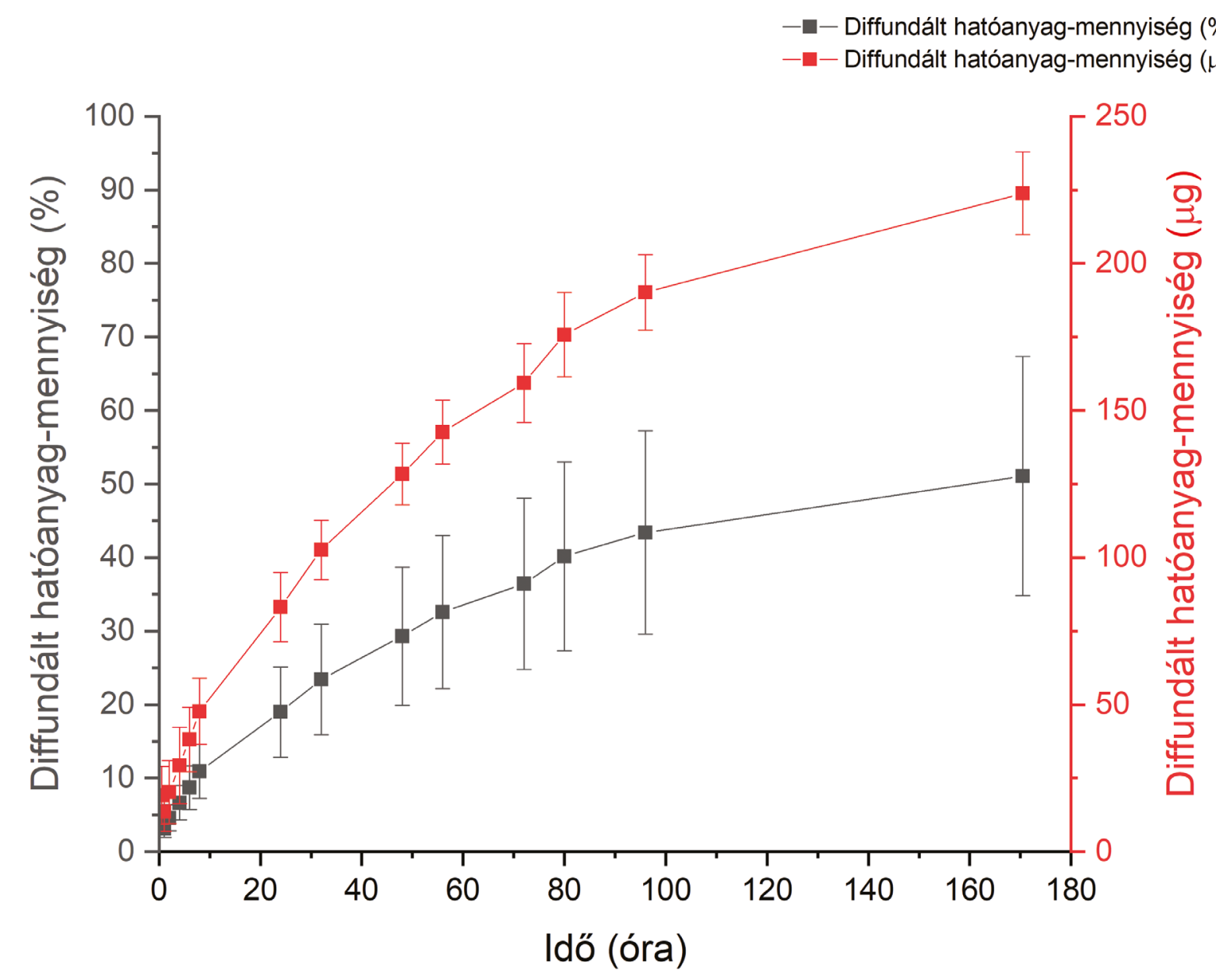

3. kép: A hatóanyag diffúziója a rendszerekből \%-osan (szürke) és $\mu g$-ban (piros) megadva 


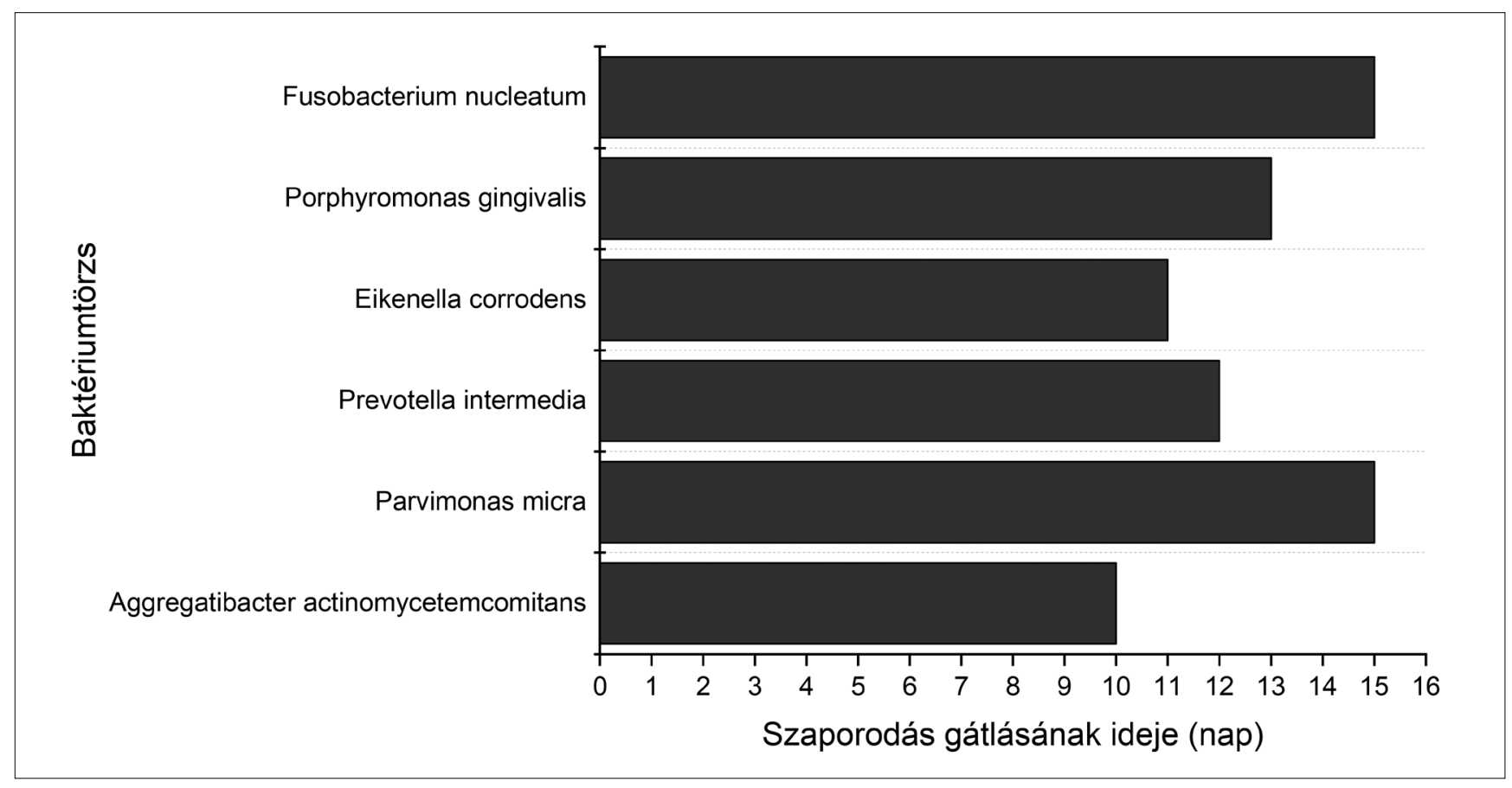

4. kép: A kísérletben alkalmazott baktériumtörzsekre vonatkozó szaporodásgátlás hossza (nap)

ideig a helyükön kell maradniuk, dimenzióstabilnak kell maradniuk annak ellenére, hogy a szulkuszfolyadék kiáramlása és a lágyszövetek gyógyulása során a tasakfal feszesebbé válik. Megfelelő hatóanyag-koncentrációt kell biztosítaniuk az adott területen, és megfelelő szubsztantivitású hatóanyagot kell tartalmazniuk az alkalmazott vivőanyagnak [17]. A vivőanyag injektálhatósága vagy a testhőmérsékleten történő alakváltozás és expanzió tudja biztosítani, hogy a tasak egyedi formáját ki tudják tölteni a készítmények, ezáltal teljesítve azt a feltételt, hogy a szubgingivális régió lágy- és keményszöveti felszíneit el tudják érni a hatóanyagok $[1,17]$. A behelyezett anyag megfelelő tapadását is biztosítani kell az adott felszínhez, annak elkerülésére, hogy idő előtt kiessen és lenyelésre kerüljön [1].

Az általunk elkészített rendszerrel összefüggésben az alábbi szempontokat támasztottuk: megfelelő szilárdsággal rendelkezzen szobahőmérsékleten a jó behelyezhetőség miatt, de testhőmérsékleten lágyabbá váljon, hogy a szubgingivális tér lehetőség szerinti teljes kitöltése és a lágyszövetek elaszticitásának gyógyulás hatására bekövetkező változása miatt a helyben maradása biztosított legyen.

A rendszerek vizsgálata során egy gömb alakú szonda hatolt be a hatóanyag-hordozókba úgy, hogy azokban kb. 50\%-nyi deformációt hozzon létre. A vizsgálatot szobahőmérsékleten és testhőmérsékleten is elvégeztük, a testhőmérsékleten történő mérést már nedves közegben, hogy imitáljuk a parodontális tasakba történő behelyezést követő változásokat.

A rendszerek meglágyulásának fontos szerepe van a parodontális tasak alakjának felvételében, valamint a felületaktív anyaggal és a polimerrel közösen a vízfel- vételben is, ami hozzájárul a mukoadhezív hatás kialakulásához. Az így megduzzadt és lágy hordozó lehetővé teszi a hatóanyag elhúzódó felszabadulását.

Szobahőmérsékelten kb. $2 \mathrm{~N}$ erőhatásra van szükség, amely közel 200 g-nyi erőkifejtésnek felel meg. Ez az erő elég alacsony ahhoz, hogy akár kézzel vagy alkalmas eszközzel formázható legyen a rendszer, viszont elég nagy ahhoz, hogy csipesszel behelyezhető legyen a tasakba. Az eredmények azt mutatják, hogy a deformációhoz szükséges erőbehatás jelentősen csökken $37^{\circ} \mathrm{C}$-on, vizes közegben, azonban nem olyan nagymértékben, hogy az a rendszer teljes elfolyósodásához és gyors eliminációjához vezessen az üregből, sokkal inkább alkalmassá válik a szubgingivális tér szabálytalan alakjának felvételére. Ez az érték nagyságrendben megközelíti Agossa K. és munkatársai által kifejlesztett injektálható, majd megszilárduló, ideálisnak tűnő hatóanyag-leadó rendszer fizikai paraméterét [1].

$A z$ in vitro hatóanyag-diffúzió vizsgálatával megállapítható, hogy a hatóanyag az általunk fejlesztett rendszerekbe való inkorporálásával lehetőség van-e a diffúzió elnyújtására. $A 3$. ábrán látható eredmények alapján elmondható, hogy kb. 50\%-os hatóanyag-diffúzió történt 1 hét elteltével, ami nyújtott hatóanyag-leadásra utal. Bakó és munkatársai vizsgálták a hatóanyagként ugyancsak CHX-t tartalmazó PerioChip ${ }^{\circledR}$-ből történő hatóanyag-diffúziót különböző $p H$-értékre beállított közegekben, többek között $p \mathrm{H}$ 7,4 PBS-ben [2]. Ha az eredményeiket összevetjük az általunk végzett in vitro vizsgálattal, megállapítható, hogy míg a készítményünk esetében egy folyamatos nyújtott diffúzió jön létre az 1 hetes vizsgálat folyamán (1 hét alatt $50 \%$ ), addig a PerioChip ${ }^{\circledR}$ esetében egy ún. „burst effect” látható, amely 
24 óra alatt kb. 40\%-os felszabadulást jelent. Ezt pedig egy csekély mértékű nyújtott diffúzió követi, ami egy hét után további $27 \%$ hatóanyag felszabadulásához vezet. Ennek alapján elmondhatjuk, hogy az általunk készített rendszer folyamatosan, egyenletesebb hatóanyagleadást biztosít, erre utalnak a különböző mikroorganizmusok körül látható gátlási zónák mikrobiológiai vizsgálatunkban.

A készítményünkben hatóanyagként alkalmazott klorhexidin-diglükonátot többféle formában alkalmazzák a fogágybetegek ellátásában. Jó szubsztantivitású szer, jó plakkgátló hatással, minimális toxicitással, amely ellen az orális patogén baktériumok esetében nem alakul ki rezisztencia, bár hosszútávú alkalmazása esetén előfordulhat ez a jelenség más, multidrog rezisztens törzseknél [12, 18, 22]. Szájöblítőként és szubgingivális irrigálószerként történő használatának effektivitását nagyban korlátozza a tasakba történő gyenge penetrációja [16]. Kontrollált hatóanyag-leadású rendszerekben a klórhexidin-diglükonát mellett klórhexidin-dihidrokloridot is alkalmaznak, amelyeket szilárd és injektálható vivőanyagokba applikálnak [22].

A szulkuszfolyadék kiáramlása miatt, a szubgingiválisan injektált hatóanyagok fél életideje nem haladja meg az 1 percet, ezért effektív antibakteriális hatás csak olyan készítményektől várható, amelyek kellő gyógyszerkoncentrációt biztosítanak folyamatos kibocsátásuk révén, és megfelelő szubsztantivitással rendelkező szert tartalmaznak [17]. Stanley és munkatársai in vitro kísérletükben meghatározták a klórhexidin-diglükonát kulcs parodontopatogén baktériumok ellen hatásos minimális inhibitor koncentrációit, az Aggregatibacter actinomycetemcomitans ( $\mathrm{Aa}$ ) kivételével. A legtöbb baktérium esetében ez 8 és $125 \mu \mathrm{g} / \mathrm{ml}$ érték közé esett, egyedül a Capnocytophaga speciesek igényeltek jóval magasabb, 250-500 $\mu \mathrm{g} / \mathrm{ml}$ koncentrációt [21]. A mi kísérletünk során a hatóanyag leadása $8 \mu \mathrm{g} / \mathrm{ml}$ volt (figyelembe véve az akceptor fázis térfogatát), amely a mikrobiológiai tesztek tanulsága szerint a kiválasztott potenciális patogén törzsek, így az Aa ellen is megfelelő gátlást biztosított. Ez azt jelenti, hogy egyenletesen és folyamatosan fenntartott hatóanyag-koncentráció esetén jóval kisebb minimális inhibitor koncentrációt lehet elérni, mint egyszeri dózis esetén, ahogy a fent idézett vizsgálatban történt. A hatóanyag megfelelő szintjét, a készítményünkbe inkorporált polimer mukoadhezív hatása is biztosítja, amelynek köszönhetően a szulkuszfolyadék mosóhatása kevésbé érvényesül.

A kontrollált hatóanyag-leadású készítményekben leggyakrabban antibiotikumokat alkalmaznak, a hatóanyagok között általában a tetraciklincsoport tagjai, illetve metronidazol szerepel [22]. A destruktív fogágybetegségek terápiájában szisztémás adagolással alkalmazott legfontosabb szer a metronidazol mellett az amoxicillin, a két szer kombinált alkalmazása az első választás a destruktív fogágybetegség agresszív formájában [9]. Az amoxicillin inkorporálása nehéz feladat kontrollált hatóanyag-leadású rendszerekbe, de a hatóanyag-hordo- zónkhoz hasonló összetételü, amoxicillint tartalmazó rendszer előállításáról és vizsgálatáról már beszámoltunk korábban: az amoxicillin helyi koncentrációját kívántuk növelni, valamint a per os antibiotikum-terápia mellékhatásait kiküszöbölni egy helyi hatóanyag-hordozóba történő bejuttatással [13]. Az ugyanazon baktériumtörzseken elvégzett mikrobiológiai vizsgálataink eredményei szerint a $\mathrm{CHX}$-tartalmú rendszereink hasonló vagy jobb antimikrobás hatást voltak képesek biztosítani ugyanolyan kísérleti elrendezésben. A szaporodásgátlási időket összehasonlítva az amoxicillin az egyik vizsgált törzs esetén 9 napos, míg más vizsgált törzsek esetén minimum 10 napos gátlást volt képes biztosítani. A gátlási időket az egyes baktériumok esetében összehasonlítva az $F$. nucleatum és az $A$. actinomycetemcomitans törzseknél hasonlóak voltak, míg a $P$. micra esetében az amoxicillin hatékonyabbnak bizonyult. A többi baktériumtörzs esetében a $\mathrm{CHX}$ minden alkalommal hosszabb idejű gátlást volt képes biztosítani, mint az amoxicillin.

Egy másik korábbi közleményünkben az amoxicillin mellett más hatóanyagokkal is elvégeztük a kísérletet [14]. A rendszerekbe mukoadhezív polimerként és hatóanyagként egyaránt alkalmazható cink-hialuronátot (ZnHA) vittünk be metronidazol mellé. A mikrobiológiai hatékonyság vizsgálata során azt találtuk, hogy a ZnHA és metronidazol kombináció hasonló hatékonyságú az amoxicillinnel és a jelen kutatásban vizsgált CHX-nel. A CHX lipid formuláció összehasonlítva a metronidazol és ZnHA kombinációval minden baktérium esetében hasonló hatékonyságot mutatott.

In vitro vizsgálatunkban nem modelleztük azokat a tényezőket, amelyek a hatóanyag felszabadulását, illetve annak effektivitását befolyásolják. A természetes fogak melletti szubgingivális térben, illetve az implantátum melletti szubmukozális területen a kialakuló biofilmek enyhén savas közegben növekednek egészséges és gyulladt lágyszövetek esetén egyaránt, de a tasak mélyülése és a gyulladás mértékének növekedése a szulkuszfolyadék kémhatását savas irányba változtatja meg $[5,6,23]$. A peri-implantáris térben, a parodontális területhez viszonyítva, alacsonyabb $\mathrm{pH}$-t mérhetünk, amelyet a dohányzás tovább fokozhat [11]. Bonesvoll és munkatársai már közel fél évszázada, röviddel a klórhexidin fogászati alkalmazásának elterjedését követően megállapították, hogy alacsonyabb pH érték mellett a klórhexidin antibakteriális aktivitása csökken, mivel savasabbá váló közegben kisebb mértékben tudnak molekulái a szájban lévő sejtek és a biofilm baktériumainak sejtfalához kötődni [3]. Ezt a hatást némileg ellensúlyozni tudja, hogy a hidrolizált zselatin mátrixba ágyazott klórhexidint leadó PerioChip ${ }^{\circledR}$ savas közegben gyorsabb és nagyobb mértékű hatóanyag-leadást produkált, mint semleges vagy enyhén lúgos kémhatás mellett [2]. Mi a készítményünk hatóanyag leadását csak PBS pufferben vizsgáltuk, így arra a kérdésre csak további vizsgálatokkal tudunk választ adni, hogy az egyébként effektív antimikrobiális hatás hogyan változik savas pH-n. 
Jelen kutatásban egy klórhexidint tartalmazó lipid alapú hordozórendszer vizsgálatát végeztük el. A rendszerek szilárdságának vizsgálata alapján elmondható, hogy azok szobahőmérsékleten kellő szilárdsággal rendelkeznek, és ez kellő mértékben meglágyul testhőmérsékleten ahhoz, hogy a célkitǔzésben megadott feltételek teljesüljenek. A hatóanyag-diffúziós vizsgálatok során megállapítottuk, hogy nyújtott hatóanyag-diffúzióval távozik a $\mathrm{CHX}$ a rendszerekből, ami szükséges egy hosszan tartó, antimikrobás hatás kialakulásához. Az eredmények összehasonlíthatók a forgalomban lévő, ugyanazon indikációban alkalmazott PerioChip ${ }^{\circledR}$ kioldódási eredményeivel, és 1 hetet követően közel hasonló százaléknyi mennyiségú hatóanyag diffundált a hordozókból. A mikrobiológiai hatékonyságvizsgálat eredményei alátámasztják a nyújtott hatóanyag-leadás lehetőségét, ugyanis legalább 9 napig voltak képesek a baktériumok szaporodását gátolni. Korábban publikált eredményeinkkel összehasonlítva, hasonló összetételű hordozórendszerek esetén, a $\mathrm{CHX}$-t tartalmazó összetételek hatékonysága hasonló a hatóanyagként amoxicillint vagy ZnHA és metronidazol kombinációt tartalmazó rendszerekhez, viszont érdemes figyelembe venni, hogy a $\mathrm{CHX}$ használata a bakteriális rezisztencia kialakulásának szempontjából előnyösebb is lehet.

\section{Irodalom}

1. Agossa K, Lizambard M, Rongthong T, Delcourt-Debruyne E, Siepmann J, Siepmann F: Physical key properties of antibiotic-free, PLGA/ HPMC-based in-situ forming implants for local periodontitis treatment. Int J Pharm 2017; 521: 282-293. https://doi.org/10.1016/ j.ijpharm.2017.02.039

2. Bakó J, Varga I, Bágy K, Lampé I, Hegedüs V, Blum I, Hegedüs Cs: PerioChip klórhexidin-glükonát felszabadulásának vizsgálata különböző pH-k esetén. Fogorv Szle 2019; 112: 34-40.

3. Bonesvoll P, LöKKen P, Rölla G: Influence of concentration, time, temperature and $\mathrm{pH}$ on the retention of chlorhexidine in the human oral cavity after mouth rinses. Arch Oral Biol 1974; 19: 10251029. https://doi.org/10.1016/0003-9969(74)90089-2

4. Drisko $\mathrm{CH}$ : Nonsurgical periodontal therapy. Periodontol 2000 2001; 25: 77-88. https://doi.org/10.1034/j.1600-0757.2001.22250106.x

5. Fujikama K, Numasaki H, Kobayashi M, Sugano N, Tomura S, Mura S: $\mathrm{pH}$ determination in human crevicular fluids. Examination of the $\mathrm{pH}$ meter and evaluation of the correlation between $\mathrm{pH}$ level and clinical findings or the microflora in each periodontal pocket. $\mathrm{Ni}$ hon Shishubyo Gakkai Kaishi 1989; 31: 241-248. https://doi.org/ 10.2329/perio.31.241

6. GaLGUt PN: The relevance of $\mathrm{pH}$ to gingivitis and periodontitis. J Int Acad Periodontol. 2001; 3: 61-67.

7. Graziani F, Karapetsa D, Alonso B, Herrera D: Nonsurgical and surgical treatment of periodontitis: how many options for one disease? Periodontol 2000. 2017; 75: 152-188. https://doi.org/10. 1111/prd.12201

8. Haffajee AD, Cugini MA, Dibart S, Smith C, Kent RL, Socransky SS: The effect of SRP on the clinical and microbiological parameters of periodontal diseases. J Clin Periodontol 1997; 24: 324-334. https:// doi.org/10.1111/j.1600-051X.1997.tb00765.x

9. JePSEN K, JePSEN S: Antibiotics/antimicrobials: systemic and local administration in the therapy of mild to moderately advanced periodontitis. Periodontol 2000 2016; 71: 82-112. https://doi. org/10.1111/prd.12121

10. JonEs CG: Chlorhexidine: is it still the gold standard? Periodontol 2000 1997; 15: 55-62. https://doi.org/10.1111/j.1600-0757.1997. tb00105.x

11. Karpavicius D, Stasikelyte M, Baseviciene N, Sakalauskaite U, RatKUTE S, RAZUKEVICIUS D: The determination of $\mathrm{pH}$ of peri-implant crevicular fluid around one-piece and two-piece dental implants: A pilot study. Clin Exp Dent Res 2019; 5: 236-242. https://doi.org/ 10.1002/cre2.177

12. Kulik EM, Waltimo T, Weiger R, Schweizer I, Lenkeit K, FilipuzzIJENNY E, et al: Development of resistance of mutans streptococci and Porphyromonas gingivalis to chlorhexidine digluconate and amine fluoride/stannous fluoride-containing mouthrinses, in vitro. Clin Oral Investig 2015; 19: 1547-1553. https://doi.org/10.1007/ s00784-014-1379-y

13. Leber A, Budal-Szucs M, Urban E, Valy P, Kovacs A, Berko S, et al: Formulation and Investigation of a Lipid Based Delivery System Containing Antimicrobials for the Treatment of Periodontal Disease. Curr Drug Deliv 2018; 15: 887-897. https://doi.org/10.2174/ 1567201815666180116092354

14. Léber A, Budal-Szücs M, Urbán E, VÁlyı $P$, Gácsı $A$, Berkó $S$, et al: Combination of Zinc Hyaluronate and Metronidazole in a LipidBased Drug Delivery System for the Treatment of Periodontitis. Pharmaceutics 2019; 11 (3). https://doi.org/10.3390/pharmaceutics 11030142

15. Mombelli A, Cionca N, Almaghlouth A: Does adjunctive antimicrobial therapy reduce the perceived need for periodontal surgery? Periodontol 2000 2011; 55: 205-216. https://doi.org/10.1111/ j.1600-0757.2010.00356.x

16. Pitcher GR, Newman HN, Strahan JD: Access to subgingival plaque by disclosing agents using mouthrinsing and direct irrigation. J Clin Periodontol 1980. 0; 7 (4): 300-308. https://doi. org/10.1111/j.1600-051X.1980.tb01972.x

17. Position Paper: The Role of Controlled Drug Delivery for Periodontitis. J Periodontol 2000; 71: 125-140. https://doi.org/10.1902/ jop.2000.71.1.125

18. Quintas V, Prada-López I, Donos N, Suárez-Quintanilla D, Tomás I: In situ neutralisation of the antibacterial effect of $0.2 \%$ Chlorhexidine on salivary microbiota: Quantification of substantivity. Arch Oral Biol 2015; 60: 1109-1116. https://doi.org/10.1016/j.archoralbio. 2015.04.002

19. Quirynen M, Bollen CM, Vandekerckhove BN, Dekeyser C, PapaIOANNOU W, EYSSEN H: Full- vs. partial-mouth disinfection in the treatment of periodontal infections: short-term clinical and microbiological observations. J Dent Res 1995; 74: 1459-1467. https:// doi.org/10.1177/00220345950740080501

20. Slots J: Periodontitis: facts, fallacies and the future. Periodontol 2000 2017; 75: 7-23. https://doi.org/10.1111/prd.12221

21. Stanley A, Wilson M, Newman HN: The in vitro effects of chlorhexidine on subgingival plaque bacteria. J Clin Periodontol 1989; 16: 259-264. https://doi.org/10.1111/j.1600-051X.1989.tb01651.x

22. SZULC M, ZAKRZEWSKA A, ZBOROWSKI J: Local drug delivery in periodontitis treatment: A review of contemporary literature. Dent Med Probl 2018; 55: 333-342. https://doi.org/10.17219/dmp/94890

23. TAKAHASH N: Microbial ecosystem in the oral cavity: Metabolic diversity in an ecological niche and its relationship with oral diseases. Int Congr Ser 2005; 1284: 103-112. https://doi.org/10.1016/j. ics.2005.06.071 
Investigation of hardness and drug diffusion profile of a subgingival drug delivery system for the sustained release of chlorhexidine gluconate

Antiseptics - besides mechanical debridement - have an important role in the treatment of destructive periodontitis. Subgingival drug delivery systems containing chlorhexidine gluconate $(\mathrm{CHX})$ may enhance or be a substitute to non-surgical therapy. In this article, we investigate a $\mathrm{CHX}$-containing drug delivery system which is solid at room temperature but softens at body temperature. The examination was focused on the hardness, the drug diffusion profile and the antimicrobial effectiveness of the formulation. Hardness was analyzed with a texture analyzer equipped with a spherical probe $5 \mathrm{~mm}$ in diameter. The investigation was carried out at 25 and $37^{\circ} \mathrm{C}$. The drug diffusion from formulations was investigated for one week in PBS solution. The antimicrobial effectiveness of the delivery systems was analyzed on 6 different anaerobic bacterial strains. Results show that hardness of formulations at $25^{\circ} \mathrm{C}$ is around $2000 \mathrm{mN}$ which is suitable for handling and insertion, whereas at $37^{\circ} \mathrm{C}$ in PBS solution, hardness decreases greatly (to $800 \mathrm{mN}$ ) which contributes to the accommodation of the delivery systems to the shape of the periodontal pocket, the penetration of gingival crevicular fluid and the drug diffusion from formulations. Results of the drug diffusion study indicate that $50 \%$ of the $\mathrm{CHX}$ diffused from the formulations during the one-week period and a concentration of $8 \mu \mathrm{g} / \mathrm{mL}$ were maintained in the acceptor phase after 24 hours. Formulations effectively inhibited the growth of anaerobic bacteria for at least one week and showed similar effectiveness to formulations containing amoxicillin or the combination of metronidazole and zinc hyaluronate. Our results suggest that this delivery system alone or in combination with mechanical debridement may be effective in the treatment of periodontitis.

Keywords: periodontitis, chlorhexidine gluconate, drug diffusion, antimicrobial effectiveness

\section{Megemlékezés} $\overline{\text { Necrology }}$

\section{Dr. Joó István}

1969-2020

A taktakenézi srác, Joó Pisti nagy álma az volt, hogy fogorvos legyen. Nekifogott hát.

A Semmelweis Orvostudományi Egyetem Fogorvostudományi Karára a sárospataki Rákóczi Gimnáziumon keresztül vezetett az út.

1993-ban elkezdődtek az egyetemista évek. Jól tanult a Joó Pisti. Becsúszott egy év egészségügyi halasztás, ezért neki két évfolyama is volt. De egyetemista társai mind a jószívű, szeretnivaló, mindig vicces Joó Pistire emlékeznek.

Végzés után a katonaság, majd - egy kis kacskaringó után - a Szent Rókus Kórház Arc-, Állcsontsebészeti és Szájsebészeti Osztálya következett.

A Rókusban valódi közösségbe került Joó Pisti. A napi munka után sokszor

bent maradt beszélgetni - igaz, ezzel nem volt egyedül. A Rókus inspiráló közeg volt Joó Pisti számára is. Olyan hely, ahol jó volt lenni. A rókusi emlékeket szinte minden találkozásnál vagy telefonbeszélgetésnél felidéztük...

Eleinte nem tudtuk, hogy mennyi lelki gondja van a Pistinek. Nehezen nyílt meg. De egyszer, egy ponton sok volt neki minden. Akkor megszakadt valami. Volt a Joó Pistiben egyfajta nyughatatlanság és valami állandó útkeresés. Ő mindig jobbat, mindig tökéletesebbet akart.

A budapesti, majd a soproni praktizálás után teljesen új lappal indított. A rá jellemző teljes átéléssel és maximalizmussal, és megtalált lelki társával és támaszával, Ingriddel kezdett bele a bécsi praxisba. 2010ben a Stephansdom mellett, a Graben elején nyitotta meg az Aventurin Zahnpraxist.

A névválasztás nem véletlen, mert Joó Pisti mindig is vonzódott a spriritualitás, a megfoghatatlan világ felé. Az aventurin ásvány éppen azt a világot jelképezi, amit Joó Pisti mindig is keresett. A kiegyensúlyozott, a gondtalan és nyugodt világot.

S most, hogy idáig jutottam a Joó Pistitől való búcsúzásban, most dilemma előtt állok. Most el kell döntenem, hogy leírom-e, amit mindenki, aki ismerte Joó Pistit, persze tud. Joó Pisti saját maga döntött úgy, hogy megkeresi azt a másik világot. Azt a másik világot - valahol odaát.

Találd meg Joó Pisti! 